\title{
台湾における在来種子の保全体制の発展段階
}

一政府機関, 種苗会社, NPO の役割に関する台日韓の比較から一

\section{冨吉 満之 1 * \\ The Multi-layered Local Seed Conservation System in Taiwan: Cross-national Research of Government, Seed Companies, and NPOs in Taiwan, Japan, and Korea}

Mitsuyuki Tomiyoshi ${ }^{1) *}$

By interviewing seven organizations and institutions in Taiwan, this study investigates the current state of organizations engaged in local seed conservation activities. Then, we compare the conservation systems of local seeds in Taiwan, Japan, and Korea. The results show that activities of
NPOs (non-profit organizations) in Taiwan engaging in these activities began relatively recently. A researcher of Taiwan University played an important role in creating networks for these NPOs and other actors.

キーワード：種苗会社, NPO, 行政院農業委員会, 在来種子, 農業生物多椂性, 遺伝資源

\section{1. 背景と課題}

作物遺伝資源を構成する在来品種（伝統品種・地 方品種）は，改良品種（近代品種）の普及, 多国籍 企業や大企業による種子産業の寊占・独占が進む中 で，世界的に急速に消失している，これらの在来品 種を持続可能な形で保全・利用することは，農業に お活る生物多様性の保全や「食料への権利」論の観 点からも, 国際的に重要な課題となっている. ヨー ロッパでは有機農業者やホビーファーマーによって, 多くの在来品種が國場（on farm）で保全・利用され ているが，品種が誕生した場所とは別の地域で栽培 されている場合が多い特徴を持つ、アフリカ等の開 発途上国に打いては, 参加型開発の観点から, 農民 参加型育種についての調査が行われている. 他方, 日本に扔ける在来品種は各地の農家によって継続的 に小規模に栽培されてきた（大和田・川手，2009）. 日本を含めた東アジアの農業の特徴としては, 豊か な気象・風土条件による（1）高い土地生産性と（2） 規模の零細性が挙げられる. 在来品種の保全・利用
に関しても，東アジアの農業形態に沿った管理シス テムが想定される.

東アジアに含まれる台湾に打いても, 在来品種の 保全・利用の中心的な役割を担ってきた零細農家は, 高齢化等により減少して和り，多様な主体が関わる ことによる管理システムの構築が課題となっている. 本研究では, 日本と同様に島国である台湾を取り上 ゲ，関連組織への調査を通じて，台湾に扔ける在来 種子の保全体制の特徵を定性的に明らかにする．更 に, 政府・種苗会社・非営利組織（NPO）ごとに在 来種子の保全状況を整理した上で，日本・韓国との 比較を通じて，東アジアに打ける台湾の現状につい て考察を加える.

\section{2. 作物在来品種の保全に関する動向}

\section{（1）世界の潮流}

在来品種は, 歴史的には各地域で農家（農民）が 栽培し，母本選抜を繰り返して自家採種を行うこと によって，各地に成立していった，政府機関のジー

\footnotetext{
1) 熊本大学政策創造研究教育センター; Center for Policy Studies, Kumamoto University

*E-mail: tomiyosi@kumamoto-u.ac.jp

(地域農林経済学会
} 
ンバンクで保管される種苗なぞのフォーマルな形態 で保全される種子と比較すると, 自家採種・インフ ォーマル種子については，世界的にみても，量的な 捕捉は困難である(久野，2012）。自家採種を含め た作物遺伝資源の保全の在り方について，国際的な 議論としては大きく 2 つ流れがある.1つ目は, 遺伝資源の保全は農民が主体となって実施されるこ とで多様性が維持されるという，「保全」を重視した 視点である。例えば，世界各地に打ける農民が自分 たちの生活を維持するために持続的に作物を育てる ことが，作物遺伝資源を維持していく上で決定的に 重要であることが指摘されている（Mooney, 1979）. また，西川（2005）は，遺伝資源の保全と持続的利 用を促進するために，(1)国際機関などによる世界レ ベルでの対応，(2)国家レベルでの対応，(3)地域レベ ルでの多様な組織による対応が，それぞれ有機的に 連携することが必要であると述べている. 現実には， 大多数の農民は保全を目的として在来品種を栽培す る訳ではない, そこでは, 常に生産性やその他の要 因との関連性の中で, 農家個人でのあるいは集団で の作物栽培の多様性が維持されることになる.

2 つ目は，「農民の権利」や「食料主権」のように 国連でも議論が行わ机ている，権利との関係性の 中での管理の在り方についての議論である (Kloppenburg, 2010).

各国での実態を調査したものとしては，ヨーロッ パ怙よびアフリカ, 日本での事例研究等がある. ヨ 一ロッパでは, 小規模種子産業が農業の生物多様性 の保全・利用に果たしている役割は大きく, それら は有機農業者や趣味の園芸家との連携によって形成 されたネットワークを通じて実現している.ただし， 品種が誕生した場所とは別の地域で栽培されている 場合が多い（根本・西川, 2008). また, 欧州各地 では農業者間のネットワークに加えて, NGO, ジー ンバンクがインフォーマルな種子流通に重要な役割 を果たしてきた（今泉，2012）。

\section{(2) 比較対象としての日本}

ここで，日本で作物遺伝資源を管理する主体につ いて触れて打く. 政府系の作物遺伝資源管理組織は 独立行政法人農業生物資源研究所であり, 農業生物 資源ジーンバンクには, 2013 年時点で約 22 万点の 植物遺伝資源が登録されている。
民間企業については主に種苗メーカーや食品企業 が該当する．民間企業による作物遺伝資源の管理に ついては，財政的限界があるため，収益性が高いと 予想される資源管理に傾きがちであるといら特徴を 持つ、ただし，歴史的には各地の中小規模の種苗会 社が地域で重要な役割を果たしてきた.

戦後, 作物の改良品種の育成（品種改良）は, 米, 麦，大豆などに関しては主に都道府県の農業試験場 が担ってきた。また，野菜などについては種苗メ一 カーや一部の食品企業などが管理育成してきた背景 を持つ、しかし，様々な在来品種は，その土地の気 候風土に根ざして作られてきたものであり，生息域 外保全のみでは限界がある。 それらの地方品種は激 減しているといらが，それでも国や企業が担うには 膨大である。まして，農家がこれ以上の労力を割い て「生産性」があまり高くない地方品種を管理して いくことは厳しい，このような背景の中で，近年で は全国各地で在来種保存会が立ち上がり，また行政 主導で地域で古くから栽培されてきた作物を「伝統 野菜」として認証・支援する潮流が生まれている.

\section{（3）課題の設定}

以上の背景を基に，本研究では台湾に括ける政府 機関, 種苗会社, NPO がこれらの在来種子の保全・ 活用に果たしている役割について，日本・韓国との 比較も交兄つつ明らかにする。具体的にはまず，政 府機関による農家・民間への種苗の提供方法を整理 し，特に，個人農家や農民グループが利用できるか を検証した（課題 1)。次に種苗会社が，地域レベル で在来種子を供給する役割を担っているか，また今 後, 担い手となりえるかを検討した（課題 2 )。最後 に，全国レベル，地域レベルで在来種子を保全する NPO の活動状況と, それらがネットワーク化した活 動として展開しているかを明らかにした（課題 3).

\section{3. 対象と方法}

台湾は, 人口約 2,300 万人のらち，漢民族が $98 \%$, 原住民が $2 \%$ 占める．在来品種の保全に関わりの ある法律としては, 植物品種及び種苗法（1988 年; 2010 年改正), 原住民族基本法（2005 年）, 農村再 生条例（2010 年）が挙げられるが，作物和よび品種 の多様性の観点から明示的に在来品種の保全や利用 を位置付けた法律は見当たらない，遺伝資源に関わ 
表 1. 調査概要

\begin{tabular}{|c|c|}
\hline 調査方法 & 半構造化インタビュー \\
\hline 調査期間 & 2014 年 5 月 5 日 8 日 \\
\hline 調査対象 & 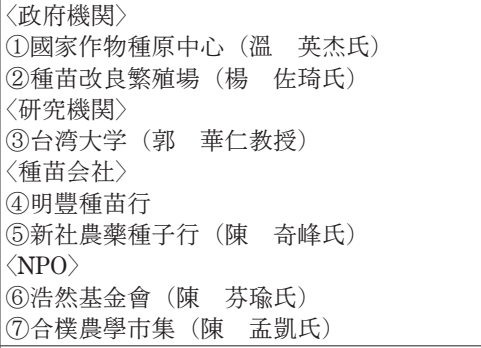 \\
\hline 調査内容 & $\begin{array}{l}\text { 種子の保全・管理状況, 他の組織との連携, } \\
\text { 事業に拈ける在来品種の位置つけ }\end{array}$ \\
\hline
\end{tabular}

注 : 表中の番号は図 1 の調査対象の番号と対応.

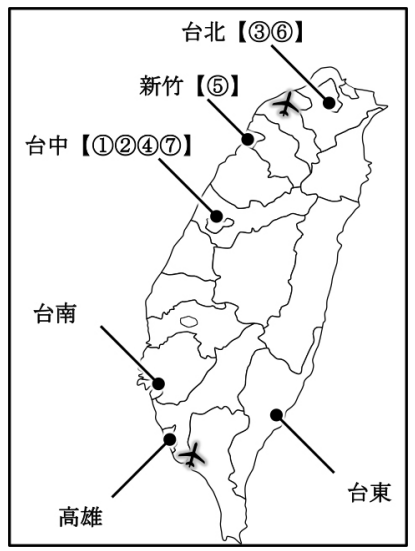

図 1. 調査対象の所在地

注 : 図中の番号は表 1 の調査対象の番号と対応.

る国際機関として，世界蔬菜センター（AVRDC）の 本部が台南に設置されている.

調査対象として, 台湾国内の 7 機関・団体を選定 した（表 1, 図 1)。2014 年 5 月に各機関を訪問し, 運営体制および種苗の管理状況に関する取り組みに ついてのヒアリングを実施した，台湾の農業統計年 報によると，調査対象が位置する首都・台北市は， 平野部と中山間地が各半分を占める. 都市化が進む ものの，イネを中心として，ダイコン，キャベッ， 八クサイなど多様な野菜が栽培されている。新竹市 は平野部が多く, 栽培される作物は, 台北市と似た 状況にある. 台中市では山間地が多いが，イネの他 にタロイモ, ジャガイモ, キャベッを中心として多 様な野菜が栽培されている.

\section{4. 結果と考察}

\section{（1）國家作物種原中心（政府系シードバンク）}

行政院農業委員会農業試験所の中の機関として, 台中市霧峰郷に 1993 年 10 月に設立された．主な業 務として(1)種苗の収集，(2)保存，(3)供給・利用，(4) 植物生殖質の保存と同定技術の 4 つがある. 保存さ れる植物遺伝資源の数は 79,755 点 (2014 年 6 月時 点）であり，185 科，784 属，1,487 種が含まれてい る. 収集されたものは, 主に海外からの品種である. 国内の品種に関しては，イネは100 年汪ど前から, 日本人による収集が行われていた，野菜に関しては， 10 年前に事業として大規模に収集が行われた．保管 されている種苗の配布も行われており, 主に研究使 用として年間 $500 \sim 2,000$ 件が配布されている. 内訳 としては，大学教授・育種家が $80 \%$ を占め，民間 $20 \%$ となっている. 個人の申請は受けていないが, 民間機関でも申請は可能である。無料で種子は提供 される。

サブバンクは国内には存在しないが，11,000 点 は,ノルウェーのノルディック・ジーンバンク (Nordic Gene Bank）に預忊られている，台湾は亜熱帯地域 に属するため，多様な果樹が分布しているが，果樹 の保存に関しては，種子での保管は難しいため，特 性によって国内の複数の試験場で植栽されている. 試験場は, 国内に 6 力所存在している.

国家としてのシードバンクがなかった時代には， 公共機関に打いて保存が行われていた.

AVRDC もシードバンクにも, サブバンクが存在 していないため, バックアップ体制は日本などと比 較すると弱い。ただし，大豆の一部については，両 機関で保管されている.

設立のキーパーソンとなったのは, Counsil of Agriculture の T. T. Chang といら台湾人で, IRRI シー ドバンクとの交流を行っていた人物である.

シードバンクの種苗について, ダイズの一部は, AVDRC から譲り受けたものである。他の種苗につ いては，それまでに公共機関で保存・改良されてき たものが中心であり，国際的な交換も実施されてい る。種苗の収集は，個別に育種家が行っていた場合 が多く，国家規模で収集事業が行われたわけでは ない.

民間の種苗会社について，農友種苗を設立したの 
は，もともと高雄にある試験場の元所長であった。 40 年前から, 野菜に関する育種の権利が民間に移譲 されたことをきっかけとして，元所長は民間に転じ ることとなった，業界第二位の生生種苗を創設した のは, AVRDC の所員だった人である.

イネに関する育種・繁殖・普及は全て政府が扱っ ている．重要な作物であるトウモロコシ，ダイズ， コムギに関しては，台湾の気候条件には適さないた め輸入が多く，よって育種に対するインセンティブ も働いていない。

\section{（2）種苗改良繁殖場}

農業委員会の傘下機関である種苗改良繁殖場は, アブラナ科, ナス科, ウリ科の作物を主に品種改良 している. 上述したシードバンクが種苗の保存を行 らことと双対の関係となっている. 品種改良の目標 や方向性に関しては, 市場のニーズがあるものを選 抜しつつ，一方で政府の目標に対応するべく両方の 目標が計画に組み入れられている. 基本的には, 民 間の種苗メーカーからのニーズが最も重視されてき た経緯を持つ。

\section{（3）台湾大学}

台湾大学農芸学系郭華仁教授は, 台湾に扮忷る在 来品種保全の第一人者である. 郭華仁教授は, ると もとは自然科学的観点から Seed biology（種苗の貯 蔵方法) の研究をしていた. 扣よそ 30 年前に国際機 関（ITPGR）にコンタクトをとったことがきっかけ となり, UPOVの育成者権（plant breeders' right）に 興味を持ち, 種苗法の改正にも関わっている. 農業 生物多様性（agro-biodiversity）についての研究を進 めるようになった。 その後, 10 年棌ど前から Organic culture's movement を始めた.

郭教授によると, 台湾では自家採種は少なく, 農 民は種苗を購入している状況にある。ただし，マメ やウリに関しては，農家は比較的採種を行っている. 日本で伝統野菜として進められているブランド化に ついては，台湾ではこれからの段階にある，農民に よる自家採種の取組みは, この $3 \sim 4$ 年に進められる ようになった段階であり, 今後, 京野菜のようなも のを作っていきたいと郭教授は考えている，その土 台となる地方品種は, 残存しているものの, 少ない といら．特に，PRに関してはまだまだである。

な抢, 農家間の種苗交換について, 在来品種の交
換は少ないのが実態である。イネは政府機関で育種 されていたものを農家は使用している。ただし，郭 教授によると，東部の原住民の集落では，自家採種 の風習が強く残っている場所がある.

2011 年，郭教授は台湾国内の $6 つ \mathrm{NPO}$ を集めて 会議を行った。そ机を踏ま兄, 各 NPO はワークシ ヨップを開き，自家採種の方法を農民達に伝える活 動を始めた。このような方法は, 参加型育種の概念 とも親和性が高いが，政府は参加型育種に対しては 積極的ではない，よって，研究者や農民が中心とな って進めていくことが計画されている.

種苗会社の変遷に関して, 台湾南部は冬に乾燥す るため，採種に適した環境にある。それに注目した 日本の種苗会社が採種技術を持ち込むようになった。 その結果, 日本の種苗会社と契約する農家が増えて いき，それらの農家から小さな種屋がでてくるよう になった。戦後は，世界中の様々な国から品種を取 り入れることで, 台湾の作物栽培の多様性は増して いった.

\section{（4）明豐種苗行}

台中市内に店を構える明豐種苗行は, 1955 年に創 業した，祖父のあとを継いだ王 振昌氏（オーナー・ 2 代目), 王 騰駿氏 (3 代目) が家族で経営してい る. この種苗店では, 固定種 (OP: Open Pollination) を取り扱っている．固定種を取り扱ら種苗店は少な くなっているが，明豐種苗行では，自分の会社の圃 場で採種した固定種の種子を国内の 100 軒程度の種 苗店に流通させている，台湾国内で固定種を生産し て採種・販売している種苗商は非常に珍しい. 扱っ ている固定種は数百種類あり, ダイコンだけでも 10 種類ある. 販売先は, 国内の他の種苗商が多い，一 万で, この地域では, 都市化により農地が減少して いるため, 家庭菜園用に購入する農家などの人数は 徐々に減っている.

王振昌氏によれば，打店としては，特に固定種を 販売したいと考えている訳ではない. 固定種の種子 は安価であるため, 収益性が低い，仕入れている F1 品種をもっと購入してもららことを希望している.

\section{（5）新社農藥種子行}

新竹縣にある種苗会社の新社農藥種子行は, 1970 年に創業した。現在のオーナーである陳奇峰氏は 2 代目で，固定種を多く取り扱ら種苗商である，先代 
表 2. 台湾・日本・韓国にお打和遺伝資源・在来種子の保全体制の比較

\begin{tabular}{|c|c|c|c|}
\hline 組織 & 台湾 & 日本 & 韓国 \\
\hline $\begin{array}{l}\text { 政府 } \\
\text { 機関 }\end{array}$ & $\begin{array}{l}\text { ・ジーンバンクの植物遺伝資源 : 約 } 8 \text { 万点 } \\
\text { ・政府は参加型育種に対して消極的 }\end{array}$ & $\begin{array}{l}\text { ・ジーンバンクの植物遺伝資源 : 約 } \\
22 \text { 万点 } \\
\text { ・政府や地方自治体などが伝統野菜 } \\
\text { の保全を支援 }\end{array}$ & $\begin{array}{l}\text { ・ジーンバンクの植物遺伝資源 : 約 } \\
20 \text { 万点 }\end{array}$ \\
\hline $\begin{array}{l}\text { 種苗 } \\
\text { 会社 }\end{array}$ & $\begin{array}{l}\text { ・採種適地としての日本の種苗会社とのつな } \\
\text { がり } \\
\text { ・OP 種, 自家採種の普及を目指す中小種苗会 } \\
\text { 社の存在 }\end{array}$ & $\begin{array}{l}\text { ・中小種苗商の減少 } \\
\text { ・在来種子に特化した種苗会社も } \\
\text { 存在 }\end{array}$ & $\begin{array}{l}\text { ・大規模種苗会社の多くが多国籍企 } \\
\text { 業により買収 } \\
\text { ・中小種苗会社の実態は不明 }\end{array}$ \\
\hline NPO & $\begin{array}{l}\text { ・大学研究者の助言のもと, 保全の取り組みを } \\
\text { 開始 } \\
\text { ・地域に根差した品種の収集・保全体制は導入 } \\
\text { 時期 } \\
\text { ・全国ネットワーク化の開始 }\end{array}$ & $\begin{array}{l}\text { ・全国組織, 県レベルの組織, 地域 } \\
\text { レベルの組織が各地で活動 } \\
\text { ・多数の様々な規模の組織 }\end{array}$ & $\begin{array}{l}\text { ・全国レベルの農民組織が存在し, } \\
\text { 調査・連携 } \\
\text { ・社団法人が株式会社と連携して保 } \\
\text { 全・普及 } \\
\text { ・少数の大規模な組織 }\end{array}$ \\
\hline
\end{tabular}

注 : 現地調査の結果伃よび冨吉・西川（2012），冨吉他（2013）をもとに作成.

は農家であり，自分で採種をして，それを他の農家 に販売していたことが，創業のきっかけとなった. 店舗は家族経営であるが，台南や雲林，海外での採 種事業も展開している. 具体的には契約農家に依頼 して採種を行っている. 採種農家の収益の安定化の ために，全量購入を基本としている.

新竹縣のこのあたりの地域は, 昔は日本向けの輸 出用の種子を採種（増殖）している地域であった.

陳氏は，農家がそれぞれ自分で採種を行らょうに なってほしいと考えている.ただし，個別の販売に 関しては，農家の栽培目的によって F1 打よび固定 種の中から，より美味しい品種を奨めるようにして いる，例えば，キュウリに関しては，F1を購入する 農家が多い.F1 の方が収量が多いため, 注とんどの 農家が F1 品種を購入していく。この地域では都市 化が進み, 農家が減少している. 現在では, 周辺の 地域の農家が種子を多く購入していく状況となって いる.

\section{（6）浩然基金會}

台湾の新幹線の建設を実施した企業の代表者が設 立した財団法人である. 2009 年の台風がもたらした 災害により，農業生産地が大きな被害を受けた。農 業関連への災害支援を進めていたが郭教授と知り合 ったことをきっかけとして，在来品種の保全に関わ る活動を進めることになった. 自らが直接的に在来 品種の保全を行っている訳ではないが, 中間支援組 織として，今後いっそら重要な役割を果たしていく と考えられる.

\section{（7）合樸農學市集}

任意団体であり，30 軒以上の有機農業者メンバー が出店する形で，月に 2 回，ファーマーズマーケッ トを展開している。 スタッフは 4 人で，2011年よ り，タネのプロジェクト（在来品種の保全活動）を 開始した。 まず，タイの NGO を訪問し，そこで展 開されている地方品種の採種方法について学ぶと共 に，その団体の「種子を代々，自分で残すことが重 要である」といら理念に触れた。

作物としてはイネを対象とし, 蓬莱米や在来米 (イ ンディカ種）を取り扱ら。1 年目には，タイからい くつか種苗を取得してきたが，2 年目以降は，市場 で購入してきた品種を用いて，そこから選抜を行っ ている. 在来米については, 国の試験場から提供を 受けた品種を使用している。本選抜の技術は，タ イの団体で学んだ技術执よび国の種苗改良繁殖場の 技術に倣っている。 このプロジェクトでは，イネで の自家採種のモデルをつくり，それを農家に広めて いくことを目標としている. 種苗交換のワークショ ップも企画されている.

\section{4. 在来種子保全に関する台日韓の特性}

前節でみた台湾の各団体の活動実態について, 政 府組織, 種苗会社, NPO ごとの特徵を整理する. 表 2 で, 先行研究で示されている日本と韓国の特徵を 併記し，東アジアに打ける 3 か国比較を試みた。

まず，政府機関に関しては，ジーンバンク（GB) での遺伝資源の管理規模を見ると，人口の割合で見 ても，台湾の GB の規模は小さくない（人口：台湾 
2.3 千万人，日本 1 億 2 千万人，韓国 5 千万人)。 た，日本の政府・行政機関が，伝統野菜の保全など を各地で支援する状沉と比較して，台湾の政府機関 は在来種子の保全にそれ汪ど積極的とは言光ない状 況にあった，課題 1 亿関して，農家・農民が政府機 関の種苗にアクセスできる状沉にはなく，西川 （2005）が述べた国家レベルと地域レベルの対応と が有機的に連携することは，現段階では確認されな かった.

次に種苗会社に関して，韓国とは異なり，台湾で はバイオメジャーによる国内の大手種苗会社の買收 は行われていない状況にあった，その要因としては， 台湾の農家は様々な作物を小規模に作っている場合 が多いことが予想される，そのため，海外メーカー は台湾の種苗メーカーを買収したとしても, 収益が 期待できず，買収するメリットが少なかったことが 挙げられる，台湾で栽培される品種は，日本や海外 から近年になって導入されて改良されてきたものが 多く，国際的にみれば小規模なマーケットと見なさ れていた可能性がある。一方で，冨吉他（2013）が 指摘しているょうに，韓国では大手種苗メーカーの 多くが外国資本によって買收されている。韓国では, 中国の東北地方の食生活に合った作物も栽培されて おり，海外メーカーは両国の種苗市場への影響力が あるとみて，買収する価值を感じていたものと考兄 られる。

また，課題 2 に関して，台湾では在来種子を取り 扱ら中小の種苗会社が存在している状沉にあった。 各種苗会社の在来種子に対する姿勢は，積極的な場 合も，そらでない場合もあったが，いずれにせよ， こ北らの種苗会社の存在が, 地域の品種の多様性に 貢献していることが分かる. 各国のこのよらな種苗 会社の多鿒を比較することはできないものの，地域 の種苗会社の存在は地域に抢忊在来種子の供給に 資する役割を担っていた。すなわち，このよらな中 小種苗会社の存在は, 現在の東アジアの工業化が進 んだ国に沶いても重要であることが示唆された。

最後に, 課題 3 の NPO 活動に関して, 地域レべ ルでの活動は見られたものの, 各地域の在来種子を 収集・保全する段階にまで至っている活動は確認さ れなかった。 日本各地で NPO や在来種保存会によ る活動が進んでいる状沉と比較すると，台湾の農家
やNPO による保全活動は，最近になって始まった 段階にあるといえる。一方，台湾大学の郭教授への 追加調査から，台湾国内の NPO が集まり「農民保 種運動（Farmers' Conservation of Seeds)」と呼ばれ るネットワーク化事業が 2013 年から始まっていた。 よって，全国的なネットワーク化も開始されており， 今後の展開が期待された。政府は参加型育種の取り 組みに対しては積極的でないため，研究者や農民が 中心となって活動を進める必要性がある. 台湾では, これらの活動について, 大学研究者が指導的・中心 的な役割を果たしていることが明らかにされた。

\section{謝辞}

台湾大学の郭華仁教授からは調査先の紹介など多 くの面でご支援頂いた．金沢大学交換留学生の洪若 綾氏には，台湾の訪問先との調整や調査地での通訳 としてご協力頂いた. 龍谷大学の西川芳昭教授には, 調査の一部に同行頂くと共に，貴重なご意見を頂い た．記して感謝申し上げる。な抒，本研究は，科研 費（25850160）の助成を受けて実施された。

\section{引用文献}

今泉 晶（2012）「EUに抢ける在来種保全と種子制度」『農業 と経済』78(13)，56-60.

大和田興・川手督也（2009）「農民主体の作物遺伝資源管理の 今日的意義」『2009 年度日本農業経済学会論文集』, 338345.

冨吉満之・西川芳昭（2012）「農業生物多様性の管理に関わる $\mathrm{NPO}$ の社会的機能と運営特性」西川芳昭編著『生物多様性 を育先食と農』コモンズ，45-67.

冨吉満之・西川芳昭・金 氣興・李 柱炅 ・ 久野秀二 $(2013)$ 「韓国に抢ける種子管理に係る諸組織の機能に関する一考 察」『農林業問題研究』49(1), 125-130.

西川芳昭（2005）『作物遺伝資源の農民参加型管理』農山漁村 文化協会.

根本和洋・西川芳昭（2008）「近代農業における小規模種子産 業の役割一農業に打ける生物多様性保全から見たヨーロッ パ事例の普遍性と特殊性一」『信州大学環境科学年報』30, 67-71.

久野秀二（2012）「誰がタネを制するか? 一種子ビジネスの現 状と対抗運動の可能性」『農業と経済』78(13), 5-21.

Kloppenburg, J. (2010) Seed sovereignty: the promise of open source biology. In: H. K. Wittman, A. A. Desmarais, and N. Wiebe (eds.) Food Sovereignty: Reconnecting Food, Nature and Community. Oakland: Food First Books, 152-167.

Mooney, P. R. (1979) Seeds of the Earth: A Private or Public Resource? Ottawa: Canadian Council for International Cooperation. 